\title{
ЕКОЛОГІЧНЕ ПРАВО
}

\section{ВИКОРИСТАННЯ I ЗБЕРЕЖЕННЯ ВОДНИХ РЕСУРСІВ В УКРАЇНІ: СУЧАСНИЙ СТАН ІМПЛЕМЕНТАЦІЇ НОРМ ПРАВА ЄВРОПЕЙСЬКОГО СОЮЗУ}

\author{
М.А. ДЕЙНЕГА, кандидат юридичних наук, доцент, \\ доцент кафедри аграрного, земельного та екологічного права \\ імені академіка В.3. Янчука, \\ Національний університет біоресурсів і природокористування України \\ E-mail:marinad@meta.ua
}

Анотація. У статті аналізується сучасний стан впровадження дієвих механізмів правового забезпечення раціонального використання і збереження водних ресурсів в Україні з урахуванням вимог, встановлених міжнародними та європейськими стандартами. Задля досягнення окресленої мети досліджено правовий досвід ЄС в екологічній сфрері.

Встановлено, що основи двостороннього співробітництва між Україною та ЄС у сфері навколишнього природного середовища визначені насамперед Угодою про асоціацію 2014 р. 3 метою практичного виконання завдань задаптаціїзаконодавства України до законодавства ЄС, в Україні була прийнята ціла низка нормативноправових актів, спрямованих на організаційно-правове забезпечення цього процесу.

Визначено, що серед глобальних екологічних проблем сучасності одними 3 найбільш актуальних є проблеми у сфері використання і збереження водних ресурсів, від невідкладного вирішення яких залежить подальше життя та здоров'я людини. Згідно із сектором «Якість води та управління водними ресурсами, включаючи морське середовище» Національної стратегії наближення (апроксимаиії) законодавства України до права ЄС у срері охорони довкілля, наша держава має адаптувати національне законодавство насамперед відповідно до Директиви 2000/60/ЄС про встановлення рамок діяльності Співтовариства у срері водної політики -Водної Рамкової Директиви.

За результатами дослідження встановлено, що Україна активно залучена у процес імплементації водного законодавства ЄC. Водне законодавство нашоі держави є достатньо розгалуженим і розвинутим.

Ключові слова: водні ресурси, використання і збереження водних ресурсів, право ЄС, водне законодавство України, імплементація, адаптація

62 | ISSN 2663-1350 «ПРАВО. ЛЮДИНА. ДОВКІЛЛЯ» | «LAW. HUMAN. ENVIRONMENT» Vol. 10, No 4, 2019 


\section{Актуальність.}

Науково-технічний

прогрес, зростання масштабів господарської діяльності зумовлюють посилення антропогенного тиску на довкілля, що спричиняє забруднення навколишнього природного середовища, особливо водних ресурсів та атмосферного повітря, зменшуються площі лісів і родючих земель, зникають окремі види рослин, тварин, і як наслідок порушується рівновага у довкіллі. Людство вже чітко усвідомило необхідність дбайливого поводження з водними ресурсами, підтримання і відновлення їх якості, оскільки якість води належить до найважливіших характеристик водних ресурсів, що визначають можливість їх використання у різних сферах життєдіяльності людини.

Нині основними проблемами щодо раціонального використання та збереження водних ресурсів України є: забруднення водних об'єктів шкідливими та недостатньо очищеними промисловими i господарсько-побутовими стічними водами (3 майже 5 млрд куб. м стоків - 50 \% 3 перевищенням забруднених речовин); уповільнення водообміну й утворення зон застою, евтрофікація (збільшення вмісту біогенних речовин у водоймі, що зумовлює бурхливе розмноження водоростей, зменшення прозорості води і вмісту розчиненого кисню у глибинних шарах унаслідок розкладу органічної речовини мертвих рослин $\mathrm{i}$ тварин, а також масову загибель донних організмів); збільшення кількості органічних сполук у водних об'єктах, що негативно впливає на санітарно-епідемічну ситуацію та якість питної води (перевищення санітарних норм за різними показниками коливається у межах до 4 разів); інтенсивне старін- ня основних фондів водозабезпечуючого та водоохоронного призначення, низька продуктивність очисних споруд (в аварійному становищі нині перебуває $26 \%$ водопровідних мереж); недостатня самовідновлюванна та самоочисна здатності водних систем; незбалансована за водним фактором система господарювання, що характеризується високими обсягами залучення водних ресурсів у виробничу сферу та високою водомісткістю продукції; забруднення підземних вод; посилення засолення грунтів; зменшення вмісту гумусу в них; посилення ерозії берегової зони («Про Концепцію розвитку...», 2000).

Позитивне вирішення окреслених проблем, безумовно, залежить від впровадження дієвих механізмів правового забезпечення раціонального використання і збереження водних ресурсів 3 урахуванням вимог, встановлених міжнародними та європейськими стандартами.

Метою статmi є 3'ясування стану імплементації норм права Європейського Союзу у сфері використання i збереження водних ресурсів відповідно до взятих нашою державою міжнародно-правових зобов'язань.

\section{Результати.}

ПравоЄвропейськогоСоюзу (далі€C) є значним досягненням у світовій юридичній науці, що втілило у собі багатовіковий правовий досвід найбільш розвинених країн Європи, трансформувавши його в наднаціональне право - право ЄС. Інтеграційні процеси в усі сфери європейського правового простору є стратегічним орієнтиром i системоутворюючим чинником розвитку нашої держави. Україна повинна створити європей- 
ські стандарти, адаптувавши українське законодавство до права ЄС. При цьому, правовий досвід $\mathrm{CC} \mathrm{в} \mathrm{еколо-}$ гічній сфері й актуальність екологічної складової з-поміж пріоритетних засад євроінтеграційної політики нашої держави має стати цільовою стратегією для України.

Основи двостороннього співробітництва між Україною та ЄС у сфері навколишнього природного середовища визначені у главі 6 «Навколишнє середовище» Угоди про асоціацію від 27.06. 2014 р., що ратифіковано Законом України від 16.09.2014 р. («Угода про асоціацію...», 2014). Відповідно до ст. 361 Угоди про асоціацію визначено, що співробітництво між Україною та СС має на меті збереження, захист, поліпшення і відтворення якості навколишнього середовища, розсудливе та раціональне використання природних ресурсів і заохочення заходів на міжнародному рівні, спрямованих на вирішення регіональних і глобальних проблем навколишнього середовища у таких сферах: зміна клімату; якість атмосферного повітря; якість води та управління водними ресурсами; управління відходами та ресурсами; охорона природи, зокрема збереження і захист біологічного та ландшафтного різноманіття тощо. Поступове наближення законодавства України до права та політики СС у сфері навколишнього природного середовища здійснюється відповідно до Додатка XXX до Угоди про асоціацію.

3 метою практичного виконання завдань 3 адаптації законодавства України до законодавства СС, в Україні була прийнята ціла низка нормативно-правових актів, спрямованих на організаційно-правове забезпечення цього процесу. Основним нор- мативно-правовим актом у цій сфері $\epsilon$ Закон України «Про Загальнодержавну програму адаптації законодавства України до законодавства Європейського Союзу» від 18.03.2004 p. («Про Загальнодержавну програму адаптації ...», 2004). Адаптація законодавства України у сфері навколишнього середовища відповідно до вимог директив $\mathrm{CC}$ передбачена як стратегічна ціль й Основними засадами (стратегією) державної екологічної політики України на період до 2020 р., які були затверджені Законом України від 21.12.2010 р. («Про Основні засади (стратегією)...», 2010) Наприкінці 2012 р. наказом Міністерством екології та природних ресурсів України від 17.12.2012 р. № 659 було затверджено Базовий план адаптації екологічного законодавства України до законодавства Європейського Союзу (Базовий план апроксимації) («Щодо затвердження Базового плану адаптації...», 2012).

На виконання положень ст. 363 Глави 6 «Навколишнє середовище» і Додатку XXX до Угоди про асоціацію у 2015 р. Міністерством екології та природних ресурсів України представлено Національну стратегію наближення (апроксимації) законодавства України до права Свропейського Союзу у сфері охорони довкілля («Національна стратегія...», 2015). Стратегія передбачає наближення законодавства України до законодавства ЄC за трьома напрямами: загальний напрям «Навколишнє середовище» (найвищий рівень), сектори («Управління довкіллям та інтеграція екологічної політики у інші галузеві політики», «Якість атмосферного повітря», «Управління відходами та ресурсами», «Якість води та управління водними ресурсами, включаючи морське

64 | ISSN 2663-1350 «ПРАВО. ЛЮДИНА. ДОВКІЛЛЯ» | «LAW. HUMAN. ENVIRONMENT» Vol. 10, No 4, 2019 
середовище», «Охорона природи», «Промислове забруднення та техногенні загрози», «Зміна клімату та захист озонового шару» та «Генетично модифіковані організми») та окремі джерела права СС, наведені у Додатку XXX до Угоди про асоціацію.

Серед глобальних екологічних проблем сучасності одними 3 найбільш актуальних є проблеми у сфері використання i збереження водних ресурсів, від невідкладного вирішення яких залежить подальше життя та здоров'я людини. Згідно із сектором «Якість води та управління водними ресурсами, включаючи морське середовище», визначеного Національною стратегією наближення (апроксимаціï) законодавства України до права ЄC у сфері охорони довкілля, наша держава має адаптувати національне законодавство відповідно до Директиви 2000/60/ЄС про встановлення рамок діяльності Співтовариства у сфері водної політики (т.з. Водна Рамкова Директива) («Водна Рамкова Директива...», 2006) зі змінами й доповненнями, внесеними Рішенням № 2455/2001/СС і Директивою 2009/31/СС; Директиви 2007/60/СС про оцінку та управління ризиками затоплення; Директиви 2008/56/СС про встановлення рамок діяльності Співтовариства у сфері екологічної політики щодо морського середовища; Директиви 91/271/СЕС про очистку міських стічних вод зі змінами й доповненнями, внесеними Директивою 98/15/СС та Регламентом (СС) № 1882/2003 і Регламентом (СС) № 1137/2008; Директиви 98/83/ ЄС про якість води, призначеної для споживання людиною, зі змінами й доповненнями, внесеними Регламентом (СС) № 1882/2003 і Регламентом (СС) № 596/2009; Директиви 91/676/
ЄЕС про захист вод від забруднення, спричиненого нітратами 3 сільськогосподарських джерел, зі змінами й доповненнями, внесеними Регламентом (ЄC) № 1882/2003.

Україна активно залучена у процес імплементації водного законодавства ЄС. Водне законодавство нашої держави є достатньо розгалуженим i розвинутим. Одним із головних документів у сфері забезпечення якості водних ресурсів є беззаперечно Водний кодекс України від 06.06.1995 р. (Водний Кодекс України, 1995), який у комплексі із заходами організаційного, правового, економічного і виховного впливу, сприяє формуванню водно-екологічного правопорядку й забезпеченню екологічної безпеки населення України, а також більш ефективному, науково обгрунтованому використанню вод та їх охороні від забруднення, засмічення і вичерпання, забезпечує додержання якості водних ресурсів.

3 метою визначення основних напрямів державної політики у сфері водного господарства, збереження і відтворення водних ресурсів, підвищення їх якості, впровадження системи інтегрованого управління водними ресурсами за басейновим принципом Верховною Радою України 24.05.2012 р. було прийнято Закон України «Про затвердження Загальнодержавної цільової програми розвитку водного господарства та екологічного оздоровлення басейну річки Дніпро на період до 2021 р.» («Про затвердження Загальнодержавної цільової програми розвитку...», 2012). Відповідно до Програми розвиток водного господарства нашої держави має бути спрямований на: впровадження ефективного, обгрунтованого та збалансованого механізму викори- 
стання, охорони та відтворення водних ресурсів, забезпечення сталого розвитку державної системи моніторингу вод згідно 3 міжнародними нормами; гармонізацію українського законодавства 3 міжнародними нормами та удосконалення нормативно-правової бази щодо забезпечення якості водних ресурсів; впровадження системи інтегрованого управління водними ресурсами за басейновим принципом; підвищення технологічного рівня водокористування, впровадження маловодних та безводних технологій, розроблення більш раціональних нормативів водокористування, будівництва, реконструкції та модернізації систем водопостачання i водовідведення тощо.

Основоположним документом законодавства України, що визначає правові, економічні та організаційні засади функціонування системи питного водопостачання $є$ Закон України «Про питну воду, питне водопостачання та водовідведення» від 10.01.2002 p. («Про питну воду...», 2012), основною метою якого є забезпечення населення якісною та безпечною для здоров'я людини питною водою, що у повній мірі відображає основні цілі європейського політики у сфері питного водокористування. Важливе значення для додержання прав громадян на достатній життєвий рівень та екологічну безпеку шляхом забезпечення питною водою відповідно до встановлених нормативів також має Закон України «Про Загальнодержавну цільову програму «Питна вода України» на 2011-2020 роки» від 03.03.2005 р. («Про Загальнодержавну цільову програму...», 2005). У зазначених законодавчих актах ставиться за мету наближення вимог державних стандартів на питну воду, технологій виробництва питної води, а також засобів вимірювання i методів оцінки до відповідних технологій, прийнятих в СС.

Протягом останніх трьох років Верховною Радою України ухвалено близько 20 законів на виконання Угоди про асоціацію з СС та наближення національного екологічного законодавства до норм права ЄС.

Відповідно до Звіту про основні результати роботи Міністерства екології та природних ресурсів України за 2016-2019 рр. («Звіт про основні результати...») реалізовано ряд завдань, що стояли перед нашою державою у частині імплементації норм права СС у сфері використання і збереження водних ресурсів.

Зокрема, запроваджено реформу державної системи управління водними ресурсами шляхом переходу від адміністративно-територіальної моделі управління до інтегрованого управління за басейновим принципом відповідно до вимог Водної рамкової директиви ЄС.

У рамках цієї реформи: внесено зміни до деяких законодавчих актів України щодо впровадження інтегрованих підходів в управління водними ресурсами за басейновим принципом (постановою Кабінету Міністрів Украінни від 18.05.2017 р. № 336 затверджено Порядок розроблення плану управління річковим басейном); здійснено гідрографічне та водогосподарське районування території України, встановлені межі районів річкових басейнів, суббасейнів та водогосподарських ділянок; започатковано реформування інституційної структури державної системи управління водними ресурсами та водним господарством, зокрема, Державного агентства водних ресурсів України шляхом реорганізації ді- 
ючих структур і утворення 13 басейнових управлінь водних ресурсів та 15 регіональних офісів водних ресурсів (наказом Державного агентства водних ресурсів України від 01.03.2018 р. № 95 (із змінами) затверджено структуру Державного агентства водних ресурсів України відповідно до басейнового принципу управління водними ресурсами. У межах кожного району річкового басейну (суббасейну) визначено відповідний орган управління - 13 басейнових управлінь водних ресурсів); утворено 13 басейнових рад дорадчо-консультативних органів, які беруть участь у формуванні і реалізації державної водоохоронної політики у межах окремого району річкового басейну; забезпечено прийняття необхідних нормативно-правових актів.

Відповідно до наказу Державного агентства водних ресурсів України від 01.03.2018 р. № 95 розробляються положення про басейнові управління водних ресурсів, для кожного із визначених органів управління у межах річкового басейну (суббасейну). Так, зокрема, Державним агентством водних ресурсів України вже затверджено положення: Дністровського басейнового управління водних ресурсів (наказ від 23.01.2018 р. № 23), Басейнового управління водних ресурсів річок Прут та Сірет (наказ від 23.01.2018 р. № 24), Сіверсько-Донецького басейнового управління водних ресурсів (наказ від 24.04.2018 р. № 230), Деснянського басейнового управління водних ресурсів (наказ від 24.04.2018 р. № 231), Басейнового управління водних ресурсів річок Причорномор'я та Нижнього Дунаю (наказ від 21.05.2018 р. № 326), Басейнового управління водних ресурсів річок Приазов'я (наказ від 25.07.2018 p. № 558), Басейнового управління вод- них ресурсів річки Прип'ять (наказ від 03.08.2018 р. № 571), Басейнового управління водних ресурсів річок Західного Бугу та Сяну (наказ від 03.08.2018 р. № 572), Басейнового управління водних ресурсів нижнього Дніпра (наказ від 03.08.2018 р. № 573), Басейнового управління водних ресурсів середнього Дніпра (наказ від 06.08.2018 р. № 575), Басейнового управління водних ресурсів річки Тиса (наказ від 17.09.2018 р. № 701), Басейнового управління водних ресурсів річки Південний Буг (наказ від 17.09.2018 р. № 703).

Постановою Кабінету Міністрів України від 19.09.2018 р. № 758 затверджено Порядок здійснення державного моніторингу вод, яким реформовано існуючу систему державного моніторингу вод відповідно до європейських принципів і підходів. Новий порядок державного моніторингу вод передбачає функціонування моніторингу вод як складової процесу розроблення планів управління річковими басейнами та морської стратегії України, оцінки прогресу й ефективності їх виконання. Головним завданням державного моніторингу вод визначено досягнення та підтримання доброго екологічного та хімічного станів масивів поверхневих вод, доброго кількісного та хімічного станів масивів підземних вод та доброго екологічного стану морських вод. Розпочато зміну існуючої системи моніторингу поверхневих водних масивів на нову, здатну забезпечувати сучасну діагностику стану водних масивів за європейськими стандартами.

Оптимізовано кількість суб'єктів моніторингу вод 311 до 5, вдвічі розширено кількість досліджуваних показників. Введено нові досліджувальні показники - гідроморфологічні, 
гідробіологічні, пріоритетні та специфічні для визначення хімічного стану вод (близько 90 показників), збільшено кількість об'єктів моніторингу вод (масиви поверхневих вод та підземних вод, морські води). 3 басейнові лабораторії, які знаходяться у басейнах річок Дону (суббасейн СіверськогоДінця), Дніпра та Дністра будуть здійснювати зазначені дослідження.

Забезпечено інформаційний менеджмент у сфері якості вод. Розроблено відкриті вебресурси для висвітлення інформації щодо якості вод (веб-система «Моніторинг та екологічна оцінка водних ресурсів України», інтерактивна карта забрудненості річок України «Чиста вода», опубліковано набори відкритих даних). 07.02.2019 р. на засіданні Міжвідомчої робочої групи 3 координації впровадження Протоколу про воду та здоров'я схвалено проект Національних цільових показників до Протоколу про воду та здоров'я та проект Плану заходів з впровадження Україною Протоколу про воду та здоров'я на 2019-2030 pp., доопрацьовані експертною групою $з$ урахуванням зауважень та пропозицій, наданих членами Міжвідомчої робочої групи, та за результатами громадських консультацій, що відбулись 19-20.12.2018 р. у м. Києві.

Крім того, вперше здійснено комплексний моніторинг стану Чорного моря відповідно до вимог законодавства $€ C$, спільно з науковцями з країн $€ C$ та Грузії здійснено три експедиції 3 дослідження стану Чорного моря. На базі отриманих даних, розпочалась розробка повноцінної Морської Стратегії. Розроблено структуру Стратегії морської природоохоронної політики України на період до 2032 року. Започатковано проект EMBLAS+ для активізації міжнародного співробітництва в рамках Кон- венції про захист Чорного моря від забруднення за участі експертів СС.

Удосконалено законодавство щодо спеціального водокористування, значно спрощено процедуру отримання документу дозвільного характеру, зокрема: внесено зміни до Водного кодексу України у частині встановлення чіткого порядку видачі дозволу на спеціальне водокористування, термінів розгляду документів та прийняття рішення про видачу або відмову у видачі дозволу, органу, уповноваженого з видачі дозволу та інше; постановою Кабінету Міністрів України від 13.12.2017 р. внесено зміни до деяких постанов Кабінету Міністрів України 3 питань видачі дозволів на спеціальне водокористування, удосконалено порядок розроблення нормативів гранично допустимого скидання забруднюючих речовин у водні об'єкти, актуалізовано відповідно до сучасних передових практик і підходів перелік забруднюючих речовин, скидання яких у водні об'єкти нормується; наказом Міністерства екології та природних ресурсів України від 12.04 .2018 р. № 116 затверджено форму заяви для отримання дозволу на спеціальне водокористування.

Запроваджено електронний сервіс 3 надання адміністративної послуги щодо дозволу на спеціальне водокористування в електронній формі, що дозволило бізнесу без зайвих бюрократичних процедур, самостійно, не витрачаючи часу, отримувати дозвіл online. Електронна послуга реалізує право на громадський контроль за діяльністю суб' єктів господарювання та органів виконавчої влади, мінімізує корупційні ризики шляхом публічності та прозорості всіх етапів процедури. Функціонує відкритий реєстр виданих та анульованих дозволів. 
Для забезпечення вільного доступу громадян до інформації про водні об'єкти України Державним агентством водних ресурсів України здійснюється ведення геопорталу «Водні ресурси України», який містить всебічну інформацію щодо державного водного кадастру - обліку поверхневих водних об'єктів. Геопортал розроблено в рамках реалізації проекту APENA 3 урахуванням вимог директив ЄС. Забезпечено візуалізацію водних об'єктів України відповідно до критеріїв Водної Рамкової Директиви $\mathrm{CC}$, зокрема, річок довжиною від 10 км та озер площею водного дзеркала більше 0,5 км2.

\section{Висновки і перспективи.}

Національне законодавства України, що визначає основні аспекти раціонального використання і збереження водних ресурсів, забезпечення їх якості, у більшості зазначених положень $\epsilon$ відповідним законодавству ЄС у цій сфері. Основні програми водної політики і водного господарства як України, так і СС спрямовані на: забезпечення збереження, раціонального використання і відтворення водних ресурсів, збереження водних ресурсів від забруднення, засмічення та вичерпання, створення умов для переходу до сталого та ефективного функціонування екосистем у водних басейнах, забезпечення якості водних ресурсів і поліпшення їх стану.

\section{Список використаних джерел}

1. Водна Рамкова Директива 2000/60/€С: Основні терміни та їх визначення (офіційний переклад). Київ: Консорціум компаній RODECOVERSeau-WRc, 2006. 244 c.
2. Водний кодекс України від 06.06.1995 p. Відомості Верховної Ради України. 1995. № 24. Ст. 189.

3. Звіт про основні результати роботи Міністерства екології та природних ресурсів України за 2016-2019 pp. URL: https:// menr.gov.ua.

4. Національна стратегія наближення (апроксимації) законодавства України до права Європейського Союзу у сфері охорони довкілля. Київ, 2015. URL: https:// menr.gov.ua.

5. Про Загальнодержавну програму адаптації законодавства України до законодавства Європейського Союзу: Закон України від 18.03.2004 р. № 1629-IV. Відомості Верховної Ради України. 2004. № 29. Ст. 367.

6. Про Загальнодержавну цільову програму «Питна вода України» на 2011-2020 рр.: Закон України від 03.03.2005 р. № 2455-IV. Відомості Верховної Ради України. 2005. № 15. Ст. 243.

7. Про затвердження Загальнодержавної цільової програми розвитку водного господарства та екологічного оздоровлення басейну річки Дніпро на період до 2021 р.: Закон України від 24.05.2012 р. № 4836-VI. Відомості Верховної Ради України. 2013. № 17. Ст. 146.

8. Про Концепцію розвитку водного господарства України: постанова Верховної Ради України від 14.01.2000 р. № 1390XIV. Відомості Верховної Ради України. 2000. № 8. Ст. 54.

9. Про Основні засади (стратегією) державної екологічної політики України на період до 2020 р.: Закон України від 21.12.2010 р. № 2818-VI. Відомості Верховної Ради України. 2011. № 26. Ст. 218.

10. Про питну воду, питне водопостачання та водовідведення: Закон України від 10.01.2002 р. № 2918-ІІІ. Відомості Верховної Ради України. 2002. № 16. Ст. 112.

11. Угода про асоціацію між Україною, з однієї сторони, та Європейським Союзом, Європейським співтовариством з атом- 
ної енергії і їхніми державами-членами, з іншої сторони від 27.06.2014 р.: ратифіковано Законом України від 16.09.2014 р. № 1678-VII. Офіційний вісник України. 2014. № 75. Том 1. Ст. 2125.

12. Щодо затвердження Базового плану адаптації екологічного законодавства України до законодавства Європейського Союзу (Базовий план апроксимації): наказ Міністерства екології та природних ресурсів України від 17.12.2012 р. № 659. URL: https://ips.ligazakon.net.

\section{References}

1. Vodna Ramkova Dyrektyva 2000/60/EC: Osnovni terminy ta yikh vyznachennia (ofitsiinyi pereklad) [Water Framework Directive 2000/60 / EC: Basic terms and definitions (official translation)] (2006). Kyiv: Konsortsium kompanii RODECOVERSeauWRc, 244 (in Ukrainian).

2. Vodnyi kodeks Ukrainy 06.06.1995 [Water Code of Ukraine] (1995). Vidomosti Verkhovnoi Rady Ukrainy, 24, 189 (in Ukrainian).

3. Zvit pro osnovni rezultaty roboty Ministerstva ekolohii ta pryrodnykh resursiv Ukrainy 2016-2019 [Report on the main results of the Ministry of Ecology and Natural Resources of Ukraine 2016-2019]. Available at: https://menr.gov.ua (in Ukrainian).

4. Natsionalna stratehiia nablyzhennia (aproksymatsii) zakonodavstva Ukrainy do prava Yevropeiskoho Soiuzu u sferi okhorony dovkillia [National strategy for approximation (approximation) of Ukrainian legislation to EU law in the field of environment] (2015). Available at: https://menr.gov.ua (in Ukrainian).

5. Pro Zahalnoderzhavnu prohramu adaptatsii zakonodavstva Ukrainy do zakonodavstva Yevropeiskoho Soiuzu [On the National Program of Adaptation of the Legislation of Ukraine to the Legislation of the European Union] (2004): Zakon Ukrainy 18.03.2004 № 1629-IV. Vidomosti Verkhovnoi Rady Ukrainy, 29, 367 (in Ukrainian).
6. Pro Zahalnoderzhavnu tsilovu prohramu «Pytna voda Ukrainy» na 2011-2020 [About the National Target Program «Drinking Water of Ukraine» for 2011-2020] (2005): Zakon Ukrainy 03.03.2005 № 2455IV. Vidomosti Verkhovnoi Rady Ukrainy, 15, 243 (in Ukrainian).

7. Pro zatverdzhennia Zahalnoderzhavnoi tsilovoi prohramy rozvytku vodnoho hospodarstva ta ekolohichnoho ozdorovlennia baseinu richky Dnipro na period do 2021 [On approval of the National Target Program for the Development of Water Management and Environmental Improvement of the Dnipro River Basin for the Period up to 2021] (2012): Zakon Ukrainy 24.05.2012 № 4836-Vl. Vidomosti Verkhovnoi Rady Ukrainy, 17, 146 (in Ukrainian).

8. Pro Kontseptsiiu rozvytku vodnoho hospodarstva Ukrainy [On the Concept of Water Development of Ukraine] (2000): postanova Verkhovnoi Rady Ukrainy 14.01.2000 № 1390-KhIV. Vidomosti Verkhovnoi Rady Ukrainy, 8, 54 (in Ukrainian).

9. Pro Osnovni zasady (stratehiieiu) derzhavnoi ekolohichnoi polityky Ukrainy na period do 2020 [About the Fundamental Principles (Strategy) of the State Environmental Policy of Ukraine until 2020] (2010): Zakon Ukrainy 21.12.2010 № 2818-VI. Vidomosti Verkhovnoi Rady Ukrainy, 26, 218 (in Ukrainian).

10. Pro pytnu vodu, pytne vodopostachannia ta vodovidvedennia [About drinking water, drinking water supply and drainage] (2002): Zakon Ukrainy 10.01.2002 № 2918 III. Vidomosti Verkhovnoi Rady Ukrainy, 16, 112 (in Ukrainian).

11. Uhoda pro asotsiatsiiu mizh Ukrainoiu, z odniiei storony, ta Yevropeiskym Soiuzom, Yevropeiskym spivtovarystvom z atomnoi enerhii i yikhnimy derzhavamy-chlenamy, z inshoi storony 27.06.2014 [Association Agreement between Ukraine, of the one part, and the European Union, the European Atomic Energy Community, and their

70 | ISSN 2663-1350 «ПРАВО. ЛЮДИНА. ДОВКІЛЛЯ» | «LAW. HUMAN. ENVIRONMENT» Vol. 10, No 4, 2019 
Member States, of the other part] (2014): ratyfikovano Zakonom Ukrainy 16.09.2014 № 1678-VII. Ofitsiinyi visnyk Ukrainy, 75(1), 2125 (in Ukrainian).

12. Shchodo zatverdzhennia Bazovoho planu adaptatsii ekolohichnoho zakonodavstva Ukrainy do zakonodavstva Yevropeiskoho Soiuzu (Bazovyi plan aproksymatsii) [Con- cerning the approval of the Basic Plan for the Adaptation of Ukraine's Environmental Legislation to the Legislation of the European Union (Basic Approximation Plan)] (2012): nakaz Ministerstva ekolohii ta pryrodnykh resursiv Ukrainy 17.12.2012 № 659. Available at: https://ips.ligazakon.net (in Ukrainian).

M.A. Deineha (2019). The use and conservation of water resources in Ukraine: current state of implementation of European Union Law. Law. Human.

Environment, 10(4): 62-71. https://doi.org/10.31548/law2019.04.008.

Summary. The article analyzes the current state of implementation of effective mechanisms of legal support for the rational use and conservation of water resources in Ukraine, taking into account the requirements established by international and European standards. In order to achieve this goal, the EU's legal experience in the environmental field has been explored.

It is established that the foundations of bilateral cooperation between Ukraine and the EU in the field of environment are determined first of all by the Association Agreement 2014. In order to practically fulfill the tasks of adaptation of the legislation of Ukraine to the EU legislation, a number of normative legal acts aimed at organizational - legal support of this process.

It is determined that among the global environmental problems of today, some of the most urgent are the problems in the use and conservation of water resources, the immediate solution of which depends on the further life and health of man. According to the sector "Water Quality and Water Management, including the Marine Environment" of the National Strategy for Approximation (Approximation) of EU Laws to Environmental Law, our country must first adapt national legislation in accordance with Directive 2000/60/EC Water Policy Communities - Water Framework Directive.

The study found that Ukraine is actively involved in the implementation of EU water legislation. The water legislation of our country is sufficiently branched and developed.

Keywords: water resources, use and conservation of water resources, EU law, water law of Ukraine, implementation, adaptation 